\title{
Land use, land cover and climate change impacts on the bird community in and around Lake Zeway, Ethiopia
}

\author{
Girma Mengesha ${ }^{*}$, Afweork Bekele ${ }^{2}$, Gail Fraser $^{3}$ and Yosef Mamo ${ }^{1}$ \\ ${ }^{1}$ School of Wildlife and Ecotourism, Hawassa University, P.O. box 5/128, Shashemene, Ethiopia. \\ ${ }^{2}$ Department of Zoological Sciences, Addis Ababa University, P.O. box 1176, Addis Ababa. \\ ${ }^{3}$ Faculty of Environmental Studies, York University, 4700 Keele Street, Toronto, Canada.
}

Accepted 16 December, 2013

\begin{abstract}
This study aimed to show impacts of land use and land cover change (LULCC) and climate on waterbird community structure of Lake Zeway and the surrounding areas. Purposive sampling techniques were used to collect primary data. Based on the purposive sampling techniques, 12 key informants and 12 focus group discussants were selected. A semi-structured questionnaire prepared in English and translated into Afan Oromo was used to interview the focus groups. The key informants participated in the interview under close inspection of the researcher. Field observations and literatures searches were also carried out on the impacts of LULCC, climate changes, lake hydrodynamics and biodiversity. Most $(92 \%)$ of the discussants indicated decreases in the level and width of Lake Zeway during the last 3-4 decades. The lake water withdrawal for irrigated agricultural activities in the surrounding areas was the main reason for decreases. Eleven groups (92\%) reported temperature increases and lower and unpredictable rainfall patterns as cause for the decreases. These changes reportedly resulted in decreased waterbird species diversity and abundance and changed distribution patterns across the lake and the surrounding areas. The FGD identified fish production and irrigated farm and bird habitat as the three most important values of the lake. The discussants also reported the combination of landuse and climate, or climate changes, as important drivers that altered the lake water level, wetland habitats and bird community structure. Urgent conservation measures that could reduce the impacts are needed to conserve the bird species at the lake.
\end{abstract}

Key words: Bird community, climate, changes, impacts, irrigated agriculture, land use.

\section{INTRODUCTION}

Although human-induced changes in Earth's terrestrial surface is not a recent phenomenon, the present rate, extent and intensity of land use and subsequent changes to land cover are unprecedented (Ellis and Pontius, 2011). Land use and land cover changes (LULCC) are linked to climate change, biodiversity loss and pollution of water, soil and air (Waltert et al., 2004; Ellis and Pontius, 2011).

The LULCC affect the climate of an area which in turn affects natural resources such as water, wetlands and biodiversity (IPCC, 2001; Gibbard et al., 2005). Though wetlands are important in the global cycling of water and chemicals, including greenhouse gases and stabilize climate changes, wetlands and their biota are at risk from the combined effects of the changes (Sanz, 2002; Finlayson et al., 2006). Thus, degradation of the environment, which negatively impact ecosystem processes and function, especially conversion of wetlands to irrigated lands, represent significant challenges to biodiversity (Sharsm et al., 2007). Changes to wetlands threaten bird 
species conservation although the impacts vary with specific land use type (Brambilla et al., 2011). Lukkarinen et al. (2011) showed variations in the structure of waterfowl communities with changes in land use around 15 lakes in Brazil. Land fragmentation at the local scale can also negatively impact the richness and composition of waterbird species (Guadagnin et al., 2005) and land cover changes alter bird distributions locally and regionally (Jetz et al., 2007).

Impacts of land cover change on African climate include reduction in surface water transpiration and increases in surface temperature (Maynard and Royer, 2004), which have impacted hydrological systems, particularly in East Africa. The East African Rift Valley Lakes, such as Lake Zeway in Ethiopia, have experienced fluctuations in lake level of tens to hundreds of meters in the past 200 years (Olaka et al., 2010). Climate changes coupled with water for domestic use, fisheries, small and large scale agriculture, floriculture and horticulture have altered the lake hydrodynamics (Abebe and Geheb, 2003; Zeray et al., 2006; Hengsdijk and Jansen, 2006; Olaka et al., 2010). Furthermore, Olaka et al. (2010) revealed that the water balance of the lake is dominated by rainfall and surface inflow, which are sensitive to climate change. The change in the lake water balance has negative consequences on the water inflow into lake and the lake size. Zeray et al. (2006) showed up to a $19.5 \%$ decline in total average annual inflow into the lake owing to woodland vegetation degradation and reduction in the amount of rainfall in its watersheds. Legesse et al. (2004) showed that a $4 \%$ rainfall decrease in the lake's catchment that was associated with woodland conversation to agriculture and increased temperature led to a $14 \%$ decrease in runoff and a $20-\mathrm{cm}$ decrease in the level of Lake Zeway.

Lake Zeway supports considerable aquatic and terrestrial biodiversity including birds and fishes. Its ecosystem serves as breeding and wintering ground and as a migration stopover habitat for several resident and migratory waterbird species (EWNHS, 1996). The pressures on the lake, specifically the irrigation-based agriculture that alters the lake water dynamics, could result in reduced fish and waterbird species compositions (Birdlife International, 2012). The changes in hydrodynamics have reduced the lake size and width which may subsequently reduce the lacustrine habitats for waterbird species (Birdlife International, 2012). Therefore, the waterbird species diversity, abundance and distribution might have changed in Lake Zeway and the surrounding environs. Moreover, fruit, vegetable, and cut flower producers released chemicals (fertilizers, pesticides) and Ethiopian government introduced exotic species into the lake ecosystem. This might have also reduced fish, waterbirds, and other life forms (Birdlife International, 2012). Nevertheless, no scientific study has been conducted to determine whether there is any evidence for such effects.

Birds have been used to indicate changing environmental conditions including climate changes (Oster, 1978; Reed et al., 2011). Further, local peoples' knowledge on their environment plays a vital role in natural resource research (Wurburton and Martin, 1999). Local or indigenous knowledge is acquired by the people through the accumulation of experiences, informal experiments and intimate understanding of the environment (Warren and Rajasekaran, 1993). These people also hold knowledge on previous variation in climate and weather (FAO, 2009)

This paper aimed to collect information from local people around Lake Zeway and examine the impacts of LULCC and climate changes on diversity, distribution and abundance of waterbirds of the area.

\section{MATERIALS AND METHODS}

\section{Study area}

Lake Zeway $\left(07^{\circ} 51^{\prime}-08^{\circ} 07^{\prime} \mathrm{N}\right.$ latitude $-38^{\circ} 43^{\prime}-38^{\circ} 50^{\prime} \mathrm{E}$ longitude) has an open water area of $434 \mathrm{~km}^{2}$, the third biggest of the Rift Valley lakes in Ethiopia (Figure 1) (Syvertsen, 1995; Abebe and Geheb, 2003). There are two big and three small islands located in the lake (Tulu Guduo, is the largest at $4.8 \mathrm{~km}^{2}$, while Tsedach is 2.1 $\mathrm{km}^{2}$ ). Lake Zeway is in the same drainage system as lakes Abijata, Shalla and Langano. The agro-climatic zone is classified as 'Weinadega' (Legesse et al., 2003). The wettest months are July and August.

Approximately a total of 460,000 humans live in the Woredas, an area of 403,000 ha, that surrounds Lake Zeway. According to Jansen et al. (2007) the socio-economic activities of the rural people of the Woredas involve a conventional mixed farming (growing of crops and rearing animals).

Lake Zeway is one of the Ethiopian Important Bird Areas that may support over 20,000 waterbirds on a seasonal basis (EWNHS, 1996; Birdlife International, 2012). The lake water, its shoreline and wetland habitats also serve as roosting and stop-over sites for a diverse and abundant assemblage of resident and Palearctic migratory bird species (EWNHS, 1996). For migratory birds in particular, the lake ecosystems have served as a wintering ground and stopover sites during unfavorable climatic conditions in other places (EWNHS, 1996; personal observation). The most common bird species that use the lake and its wetlands include White Pelican (Pelecanus onocrotalus, Linnaeus 1758), Marabou Stork (Leptoptilos crumeniferus Lesson, 1831) and Fulvous WhistlingDuck (Dendrocygna bicolor, Viellot, 1816) which roost in large numbers, Reed Cormorant (Phalacrocorax africanus, Gmelin, 1789), European Swallow (Hirundo rustica, Linnaeus, 1758) and Yellow Wagtail (Motacilla flava, Linnaeus, 1758) (Birdlife International, 2012). Although, the lake and its associated habitats are known to harbor various species of birds in large numbers, a combination of socio-economic and climatic factors has resulted in the loss of biodiversity in the lake (Abebe and Geheb, 2003; Legesse et al., 2003). Both the garage highland that drains to Zeway through the Meki River, and the Arsi highland that drains through the Kater River, have been seriously degraded, which has accelerated the local loss of biodiversity (Sisay, 2003; Zeray et al., 2006). Lake degradation is linked to deforestation, mainly for agriculture, industry, human encroachment and settlements (Ayenew, 2002; Jansen et al., 2007; Ayenew, 2009). The increased land use is also linked to increases in human and livestock populations leading to overgrazing, soil erosion and decreased water level and quality.

\section{Methods}

For the primary data collection and informant selection, we used purposive sampling techniques (judgment sampling) as described by Devers and Frankel (2000), Tongco (2007) and Teddlie and Yu (2007). To reduce biases that arises due to purposive sampling 
Legend
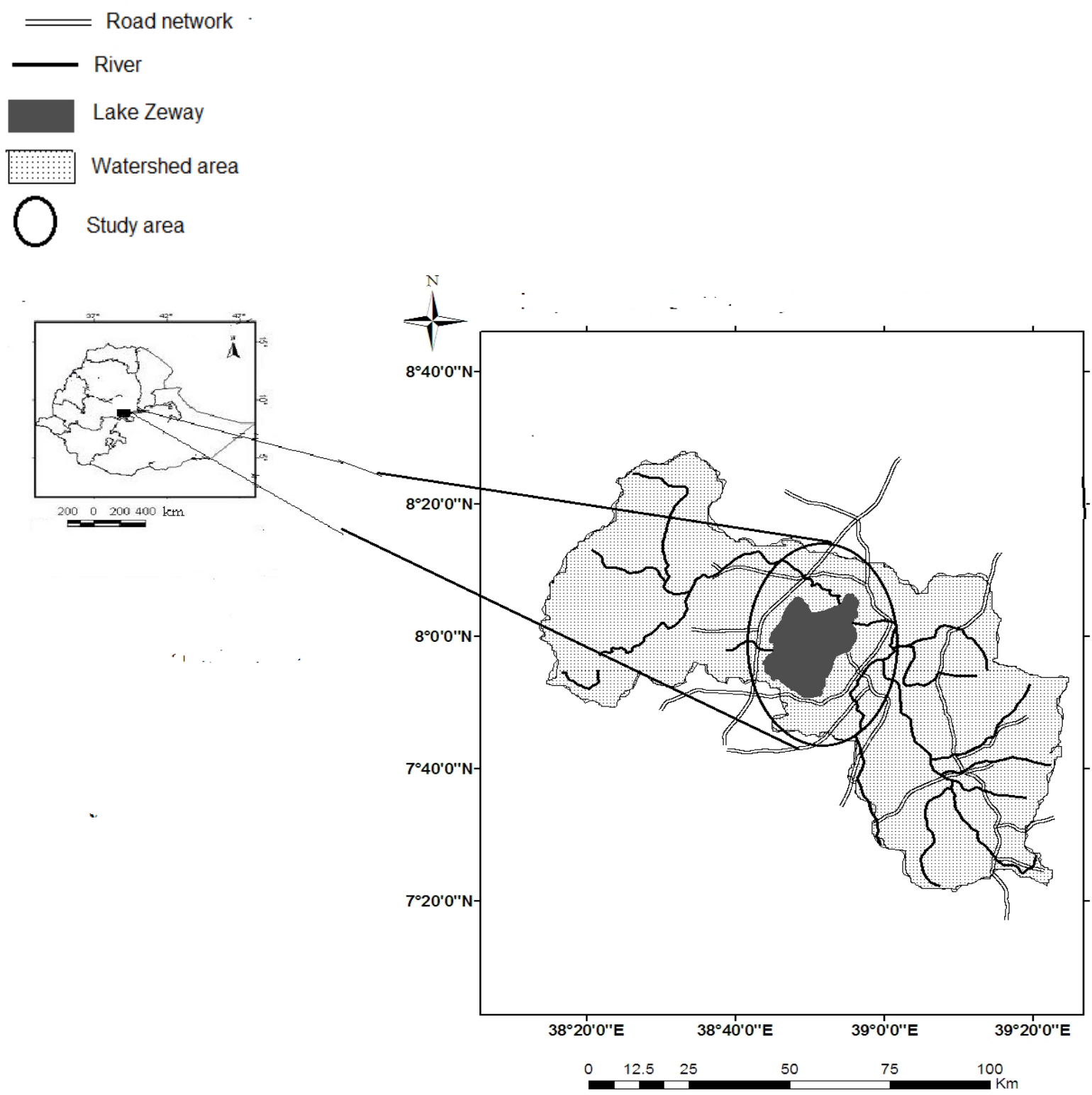

Figure 1. Map showing the location of Lake Zeway, study area in Ethiopia, and watershed area.

techniques, key interviewees were first selected from three districts ( 2 in each) and 'Kebeles' (divisions within a district) in the study area. The interviewees were selected with the help of districts or Woreda and Keble officers. In addition, the officers of agriculture and land administration of the districts in the study area assisted in the selection of the key interviewees, the key informants were those who are native and agricultural development worker in the study area.

After the key interviewees $(N=12)$ were introduced to the subject matter, each of them selected five to six additional individuals to participate in the focus group discussions (Teddlie and $Y u, 2007$ ). Thus, twelve focus groups of discussants were formed for interviews on the impacts of LULCC and climate change on the water and waterbirds of Lake Zeway and the surrounding environs. The focus group participants were purposively comprised of adults and old aged ( $\geq 60$ years) individuals who have lived for a long time in the area. The individuals were selected since they have in-depth knowledge and experience of conditions of their environs (Warren and Rajasekaran, 1993), and could provide long-term information about LULCC and climate change impacts on the lake water, its surrounding areas and its bird species. The key interviewees were used as the interviewer to the discussants and the researcher closely monitored the interview. A comparison was also made between similar literature on the impacts of LULCC and climate changes in biodiversity in the area.

Human populations that live in the 'Kebeles' adjacent to Lake Zeway $(1-1.5 \mathrm{~km})$ were selected for the study. Most of the population inhabiting these areas is from Oromo tribes whose language is Afan Oromo, and most members of other tribes in the area also speak and write in Afan Oromo, which is the official language of the region. Thus, a semi-structured questionnaire was delivered in Afan Oromo. The questionnaires were used to assess information on 


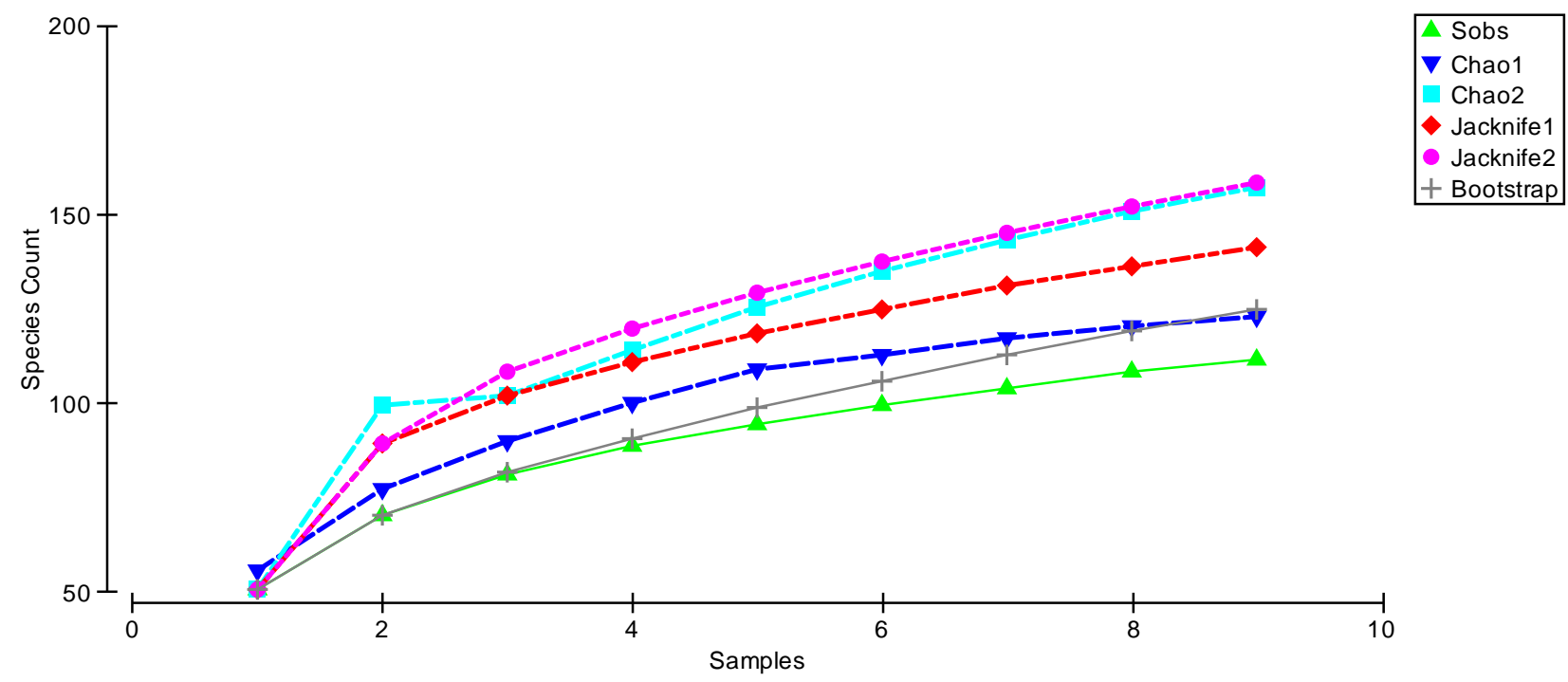

Figure 2. Bootstrap of the 1999-2008 waterbird species data.

Table 1. Temporal waterbird species richness and diversity between 1999 and 2008.

\begin{tabular}{|c|c|c|c|c|c|c|c|c|}
\hline Year & $\mathrm{N}$ & $\mathrm{s}$ & Chao1 & Chao2 & Jacknife1 & Jacknife2 & $\mathrm{H}^{\prime}$ & $\mathrm{J}^{\prime}$ \\
\hline 1999 & 1599 & 56 & 56.42 & 51.42 & 51.42 & 51.42 & 3.36 & 0.83 \\
\hline 2000 & 1854 & 48 & 77.69 & 98.76 & 89.45 & 89.45 & 3.11 & 0.81 \\
\hline 2001 & 1888 & 52 & 90.46 & 102.59 & 102.49 & 108.90 & 3.11 & 0.79 \\
\hline 2002 & 883 & 50 & 101.44 & 114.23 & 111.36 & 120.09 & 3.23 & 0.83 \\
\hline 2003 & 2223 & 51 & 09.38 & 124.68 & 118.47 & 129.17 & 2.78 & 0.71 \\
\hline 2004 & 2070 & 52 & 113.93 & 34.8635 & 125.08 & 137.89 & 2.94 & 0.7 \\
\hline 2005 & 4396 & 52 & 117.71 & 143.67 & 131.03 & 145.56 & 1.65 & 0.42 \\
\hline 2007 & 204 & 40 & 120.51 & 150.29 & 136.21 & 152.13 & 3.19 & 0.87 \\
\hline 2008 & 1619 & 62 & 123.25 & 157.38 & 141.33 & 158.83 & 3.39 & 0.82 \\
\hline
\end{tabular}

the previous and present status of Lake Zeway and its waterbirds in relation to LULCC and climate changes impacts (Appendix 1).

\section{Data analysis}

The collected data were analyzed using SPSS 15 and Microsoft Excel statistical software packages as in Asefa (2008) for assessing local people's economic and conservation perspective of biodiversity in Harrena Forest, Ethiopia. Finally $x^{2}$ was computed to test associations of discussants ranking values of Lake Zeway (Table $6)$. Statistics are given as the mean \pm standard deviation (SD).

\section{RESULTS}

A total of 131 bird species were compiled using data between 1999 and 2008 obtained from Ethiopian Wildlife and Natural History Society that was collected by African wildlife census. Some of these bird species such as Wattled Carne and Black Crowned Crane are threatened bird species of conservation concern. The species count and sample test for the species richness indicators revealed good relationship (Figure 2). The Chao 1, Chao 2,
Jacknife 1 and Jacknife 2 computed for the birds indicated lower species richness in 1999 and 2000 and almost increasing trends thereafter (Table 1). However, the bird species diversity and evenness is high during 1999 and showed decline in the year 2005 which was the lowest and increase in 2007 and 2008 (Table 1). From the data, there was no clear trend except fluctuation of decrease in some years and increase in others. The highest species abundance similarity was obtained between 1999 and 2008 but the abundance data for 2007 showed no similarity with almost all years (Table 2).

According to Vuik (2008) there were various land use types in the surrounding areas of Lake Zeway including its watershed systems where some of the areas were intensively cultivated and others used for irrigation (Figure 3). Based on Vuik (2008) and researchers, the crosschecked irrigated land around the lake was once covered by wood and wet grassland. Furthermore, researchers observed further increase in irrigated land that drastically reduced the riverine and wet grassland habitats close to the lake. 
Table 2. Temporal similarity of the waterbird species of Lake Zeway between 1999 and 2008.

\begin{tabular}{lccccccccc}
\hline & 1999 & $\mathbf{2 0 0 0}$ & $\mathbf{2 0 0 1}$ & $\mathbf{2 0 0 2}$ & $\mathbf{2 0 0 3}$ & $\mathbf{2 0 0 4}$ & $\mathbf{2 0 0 5}$ & $\mathbf{2 0 0 7}$ & $\mathbf{2 0 0 8}$ \\
\hline 1999 & & & & & & & & & \\
2000 & 38.34197 & & & & & & & \\
2001 & 55.94512 & 48.56512 & & & & & & \\
2002 & 64.7482 & 50.17026 & 58.30619 & & & & & \\
2003 & 49.11661 & 41.94842 & 59.36902 & 40.02478 & & & & \\
2004 & 43.63895 & 59.83494 & 57.19045 & 47.92139 & 52.1262 & & & \\
2005 & 11.08765 & 15.01956 & 16.9297 & 13.22894 & 17.51313 & 23.56792 & & & \\
2007 & 0 & 0 & 0 & 0 & 0 & 0 & 0 & & 1 \\
2008 & 66.19718 & 38.80884 & 43.22767 & 59.34066 & 44.98309 & 53.00067 & 12.99172 & 1.73913 & \\
\hline
\end{tabular}

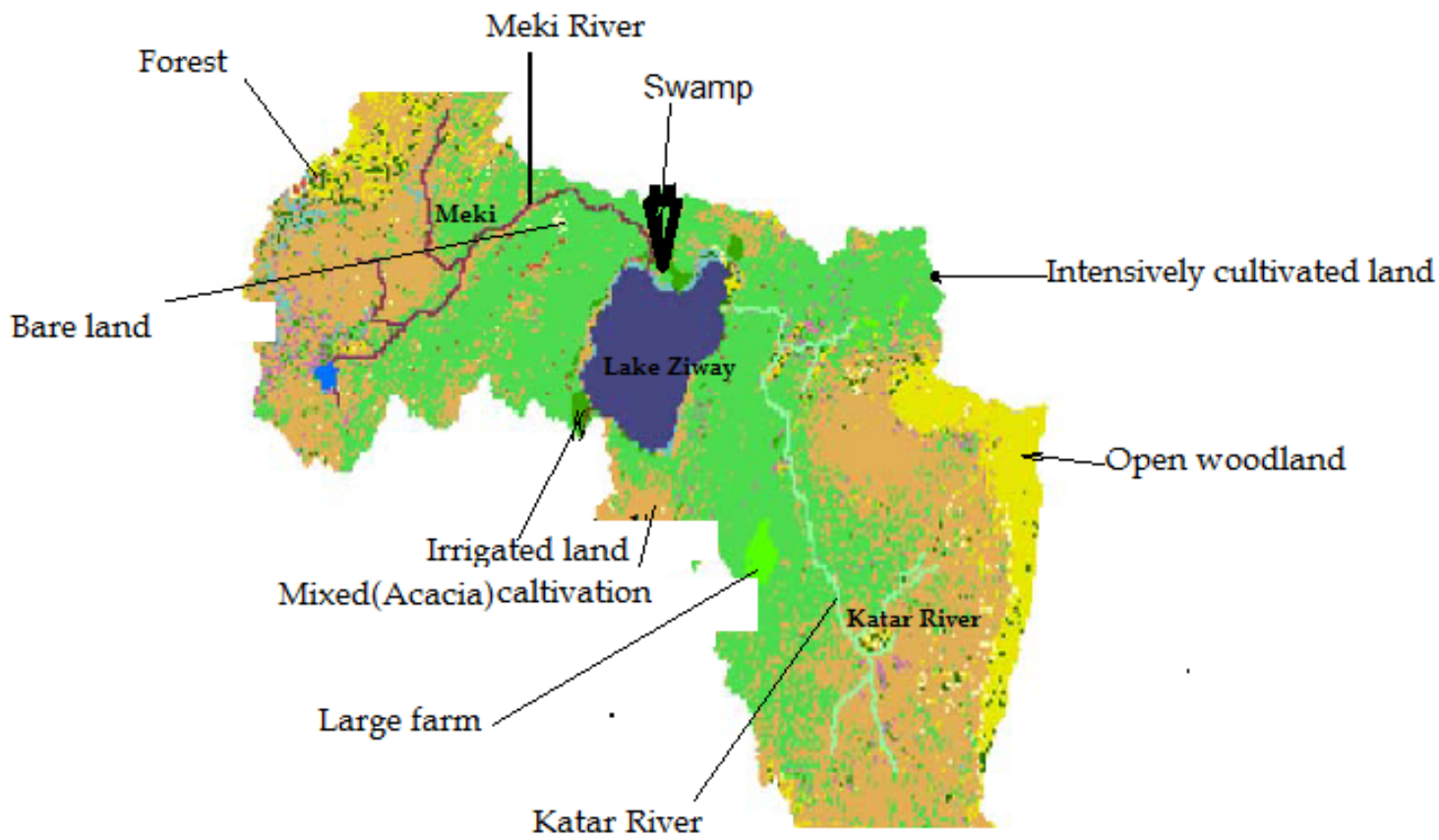

Figure 3. Land use in the surrounding area and the catchment in Lake Zeway (adopted from Vuik 2006).

Ol'ka et al. (2010) showed that the Lake Zeway was located in the range 0.23-3.00 aridity index ( $\mathrm{Al}$ ) and hypsometric integral $(\mathrm{HI}) 1$ and it is one of the most sensitive lake to local and regional climate change. Moreover, Degnenovsky and Getahun (2008) revealed fluctuations and decreasing trends of the Lake Zeway's water level in response to local and East African climate change impacts (Figure 4). Such studies show the preva-lence of climate change and its impacts on the area. In addition, other studies on water resources, land use and climate changes in the Ethiopian Rift Valley areas that include the Lake Zeway indicated existence of change in land use and climate and their impacts (Table 3).
The researchers crosschecked the current situation by observations and this proved changes in land use such as increased irrigated land, where they observed local farmers papering intact riverine wood and grassland for cultivation. In addition, researchers estimated 100-150 m lake width reduction based on platform of landmark at the previous water point (2-3 decades) and non-sampled local elders. Researchers also observed silt accumulation, high temperature, erratic rain fall, overgrazing with estimates between 60 and 10,000 individuals of livestock. Overfishing using various sized fish traps by the locals and commercial co-operatives were also noted. Few number of birds species that were once abundant in the area such as 


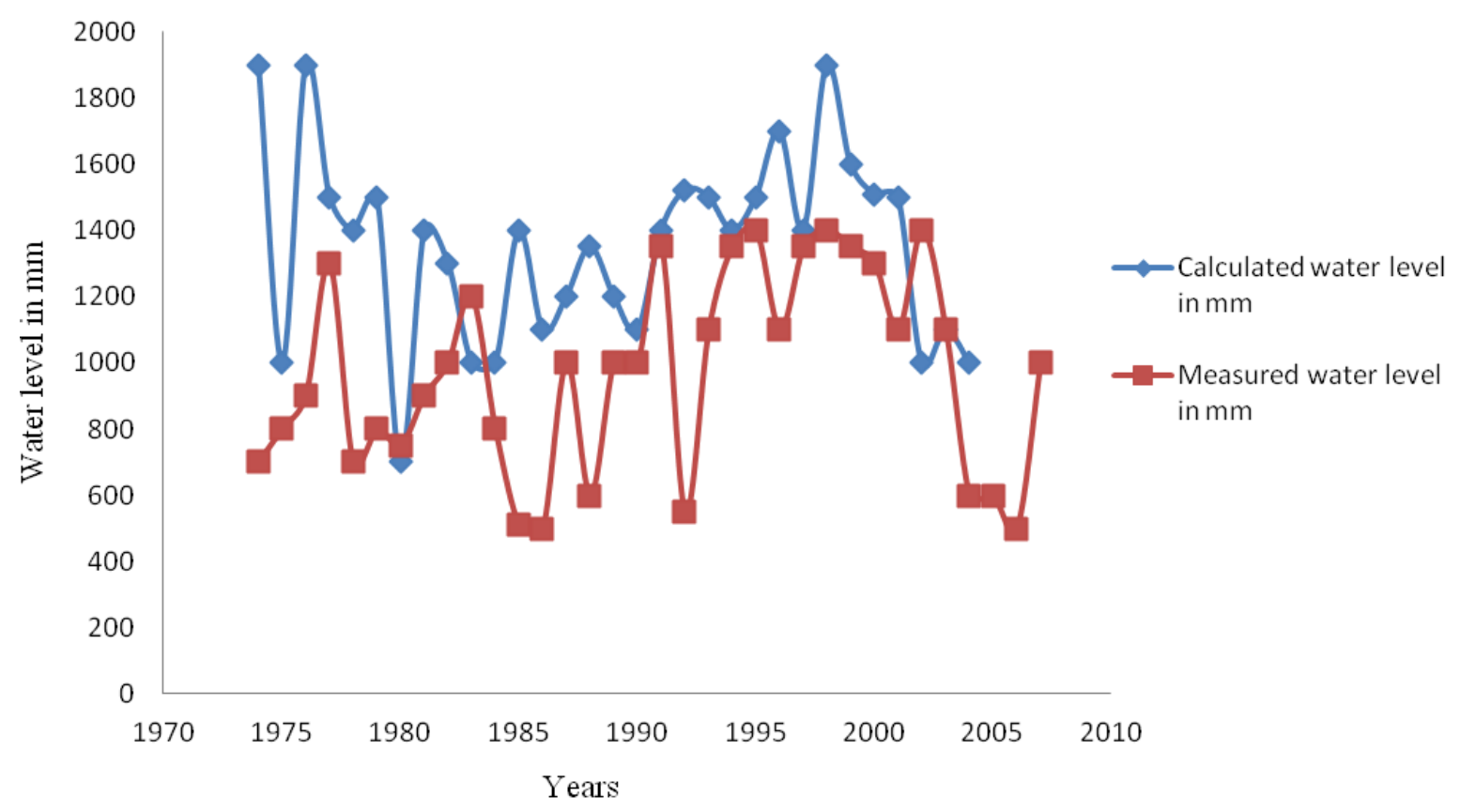

Figure 4. Lake Zeway water level oscillation (as a result of regional climate change impact) calculated amd measured (adopted from Denanovisky and Getahun, 2008).

Table 3. Impact of Land-use, land cover and climate changes on the Lake Zeway and the surrounding environs.

\begin{tabular}{|c|c|c|c|c|}
\hline Change & Trend & Impact on the lake & $\begin{array}{l}\text { Remarks (literatures or } \\
\text { researchers) }\end{array}$ & Source \\
\hline \multirow{3}{*}{$\begin{array}{l}\text { Land } \\
\text { use }\end{array}$} & $\begin{array}{l}\text { Increased Irrigated } \\
\text { agricultures (large and small } \\
\text { scale farms) }\end{array}$ & $\begin{array}{l}\text { Decrease in the level by } 0.5 \mathrm{~m} \\
\text { since } 2002\end{array}$ & $\begin{array}{l}\text { The literature assumed that this } \\
\text { negatively affect fishery and } \\
\text { aquatic birdlife }\end{array}$ & Jansen et al., 2007 \\
\hline & $\begin{array}{l}\text { Increased cultivation of the } \\
\text { catchment areas to the lake } \\
\text { (around Katar and Make } \\
\text { rivers) }\end{array}$ & $\begin{array}{l}\text { Contributed to the decrease in } \\
\text { the lake level as above } \\
\text { increased salinity and increased } \\
\text { evapo-transpiration }\end{array}$ & $\begin{array}{l}\text { The literature assumed that they } \\
\text { negatively affected fishery and } \\
\text { aquatic birdlife }\end{array}$ & Jansen et al., 2007 \\
\hline & $\begin{array}{l}\text { Increased in cultivated land } \\
\text { from approximately } 10,000 \text { ha } \\
\text { in } 1973 \text { to above } 100,000 \text { in } \\
2002\end{array}$ & $\begin{array}{l}\text { Degradation to the lake's } \\
\text { catchment areas }\end{array}$ & $\begin{array}{l}\text { The literature assumed that this } \\
\text { negatively affected fishery and } \\
\text { aquatic birdlife and other } \\
\text { biodiversity }\end{array}$ & Jansen et al., 2007 \\
\hline \multirow[t]{2}{*}{ Climate } & Temperature increase & $\begin{array}{l}\text { Increased average temperature } \\
\text { by } 1.5^{0} \mathrm{C} \text { since } 1951 \text { and evapo- } \\
\text { trnaspiration by } 3-4 \%\end{array}$ & $\begin{array}{l}\text { The literature assumed that these } \\
\text { negatively affected fishery and } \\
\text { aquatic birdlife }\end{array}$ & $\begin{array}{l}\text { National Metrological } \\
\text { Agency (NMA,2007) }\end{array}$ \\
\hline & Rainfall( no obvious trends) & & $\begin{array}{l}\text { Researchers observed erratic } \\
\text { and lower rainfall }\end{array}$ & $\begin{array}{l}\text { National Metrological } \\
\text { Agency (NMA, 2007) }\end{array}$ \\
\hline
\end{tabular}

Table 4. Characteristics of the focus group participants.

\begin{tabular}{lccccll}
\hline Parameter & N & Minimum & Maximum & Mean \pm SD & $\begin{array}{l}\text { Proportion by age, occupation, education and longevity in years } \\
\text { in the area (\%) }\end{array}$ \\
\hline Age & 65 & 28.00 & 80.00 & $50.8 \pm 13.3$ & $80 \% \geq 40$ years old & $20 \%<40$ years old \\
Occupation & 65 & - & - & - & $91.7 \%$ farmers & $6.3 \%$ others \\
Education & 65 & Basic,1-3 & $10+1$ & $2.4 \pm 4.4$ & $84.6 \%$ (basic education) & $13.4 \%$ from grade $4-10+1$ (diploma level)s \\
Longevity & 65 & 28.00 & 80.00 & $49.8 \pm 13.3$ & $77.8 \% \geq 40$ years & $32.8 \%<40$ years old \\
\hline
\end{tabular}

$\mathrm{N}=$ Number of individuals that participated in the FGD, basic education = informal or formal, grade 1-3, 10+1= after completing grade 10 and getting 1 year professional training or learning to 1 year next education level, Longevity $=$ the number of years the individual lives in the area. 
Table 5. Some of the reasons given for the decrease in the depth and width of Lake Zeway as caused by land use and climate change impacts.

\begin{tabular}{lcc}
\hline Reasons for decrease in lake depth and width & $\begin{array}{c}\text { N (frequency } \\
\text { of responses) }\end{array}$ & $\begin{array}{c}\text { Frequency of the } \\
\text { responses (\%) }\end{array}$ \\
\hline Land conversion to agriculture & 11 & 92 \\
Wetland conversion to small scale irrigated agriculture & 12 & 100 \\
Land conversion to floriculture & 10 & 83 \\
Land conversion to horticulture & 9 & 75 \\
Wetland conversion to large scale agriculture & 7 & 58 \\
Temperature increase contributed to change in lake size & 11 & 92 \\
Decrease in the amount of rain fall & 12 & 100 \\
Woody and other vegetation cover loss to agriculture by local people & 11 & 92 \\
Change of wetland to farmland & 10 & 83 \\
Change of wetland to grazing land & 6 & 50 \\
\hline
\end{tabular}

Marabou Stork, White Pelicans, Pink Backed Pelicans, Long-tailed Cormorant, African Darter and absence of Lesser Jacna, Lesser and Greater Flamingos were observed. Moreover, presence of large number of international tourists watching birds on the accessible western side of the lake where large number of pelicans and other bird species gather was seen. On this side of the lake, several investors who were constructing lodges destroying riverine vegetation were also noted. The turning up of more and more water withdrawal using large and small motor boats, new ditches that were dug as passage of water tubes were also noted during the survey period.

Furthermore, those interviewed provided their views on the impact of land use and climate changes. Most (80\%) of the individuals who participated in the focus group discussions were $\geq 40$ years old and $78 \%$ lived in the area between 1-1.5 km throughout their life time (Table 2). Most discussants (92\%) depended on mixed farming activities (growing crops and rearing domestic animals) that are directly or indirectly based on the water of Lake Zeway and its surrounding areas (Table 4). Eighty-five percent of the participants had only basic education (up to grade 3 ), while a few (13\%) had grade 4-diploma levels $(10+1$, that is completed grade 10 plus one year professional training) (Table 2). All (100\%) discussants identified LULCC and climate changes as the major environmental drivers that altered the hydrodynamics of Lake Zeway. According to 11 (92\%) of the discussants, the depth (level) of Lake Zeway has decreased because the lake is filled with silt, inflow from feeder rivers has decreased, and rainfall has become scarce and unpredictable in the area. One (8\%) of the discussants reported no change in the lake size. All 12 of the focus groups described lake water withdrawal for irrigated agriculture as contributing to the decrease. Estimates of irrigation water use are from 11 (92\%) discussants, which on average estimated that $14.8 \pm 10 \mathrm{~m}^{3} /$ day/ha of water, is pumped for irrigated agriculture. The remaining group did not estimate the amount of water pumped. Discussants who did make estimates stated that water was used for the production of cut flowers, grapes by closed irrigation, and other food crops (onion, tomatoes, cabbages and maize) by both small- and large-scale open irrigation. The lowest rates of water use $\left(4.8 \mathrm{~m}^{3} /\right.$ day/ha) were said to be used by small-scale farming and the largest (24.8 $\mathrm{m}^{3} /$ day/ha) by the Share Ethiopia Floriculture Enterprise (SEFE) that produces flowers for export. SEFE were estimated by the discussants to hold about 100 ha of land, suggesting that an estimated $2,480 \mathrm{~m}^{3}$ of water was diverted from Lake Zeway each day by the SEFE alone. All (100\%) the discussants also indicated a decrease in the width of Lake Zeway (Table 5). Woodland deforestation in the lake catchments and wetland fragmentation for expansion of agriculture were among the impacts the focus group discussants indicated for the lake width decrease. Twelve (100\%) of the groups suggested that long dry seasons and evapo-transpiration have led to the decline in the level and width of the lake.

At least half of the focus groups suggested that specific reasons for lake depth/width changes included: land conversion to irrigated agriculture (92\% of the groups), floriculture (83\%), horticulture (75\%), woodland conversion to agriculture (50\%), wetland conversion to agriculture (50\%), increased local temperatures (92\%) and decreased local rainfall $(100 \%)$.

Nine $(75 \%)$ of the focus groups indicated that the diversity (number of bird species) within and in the areas surrounding, Lake Zeway was decreasing, and that LULCC and climate changes are the major reasons. One group (8\%) indicated an increasing trend and two (17\%) did not make an assessment. Most focus groups (92\%) also thought that the abundances of bird species were decreasing. Most of the respondants (10 groups, 83\%) thought that Lake Zeway's waterbird distributions have changed.

A majority (83\%) of the discussants proposed lake water withdrawal by small- and large-scale irrigated agriculture as the most likely reason for decline in food and habitats of waterbird species and their diversity and abundance. Eight of the discussants (66\%) thought that waterbird species diversity and abundance decreases 
Table 6. Values for Lake Zeway ranked by focus group discussant.

\begin{tabular}{llllll}
\hline Values of Lake Zeway & $\mathbf{N}$ & Rank value Total & & Mean Rank \pm STD & Rank \\
\hline \multirow{3}{*}{ Fish } & 7 & 5 & 35 & & $1^{\text {st }}$ \\
Total & 3 & 4 & 12 & \\
Farming activities & 2 & 3 & 6 & \\
& 12 & & 53 & $4.4 \pm .79$ & \\
& 4 & 5 & 20 & & $2^{\text {nd }}$ \\
Total & 4 & 4 & 16 & \\
& 1 & 3 & 3 & & \\
Bird habitat & 2 & 2 & 4 & & \\
\multirow{4}{*}{ Total } & 1 & 5 & 5 & & $3^{\text {rd }}$ \\
Grazing & 12 & & 48 & $4.0 \pm 1.0$ & \\
& 2 & 4 & 8 & & \\
& 7 & 3 & 21 & & \\
Total & 3 & 4 & 12 & & \\
& 12 & & 35 & $3 \pm .67$ & \\
Tourist attraction & 1 & 5 & 5 & & $4^{\text {th }}$ \\
Total & 3 & 4 & 12 & & \\
\hline & 1 & 3 & 3 & & $5^{\text {th }}$ \\
\hline
\end{tabular}

$5=$ highest value, 4 = very high value, $3=$ high value, $2=$ low value, $1=$ very low value, STD = standard deviation.

were linked to woodland deforestation and wetland fragmentaion or conversion to irrigated agriculture. According to the focus group discussants, the decreases were caused by losses of food, cover, nest sites, stopover habitat and maintenance stations for resident and migrant birds. Five ( $42 \%$ of the discussants) suggested that chemicals, fertilizers and pestcides drain into the lake as a result of floriculture killing fish and reducing other biodiversity that waterbirds consume. The discussants stated that this could have caused the species diversity and abundance decline. Ten (83\%) of the discussants proposed that overfishing by local and commercial cooperatives at the lake has depleted the composition of fish fauna and fish-eating birds. Half (50\%) of the groups said that reductions in the worm and fish species that waterbirds consume, caused by the introduced African Catfish (Clarias gariepinus, Burchell, 1982), were rea-sons for waterbird diversity and abundance decreases. Ten (83\%) of the discussants thought that pesticides sprayed in the 1970 s by the Ethiopian government to destroy birds that are pests on cereal crops have contributed to the reduc- tion in bird species composition in the Lake Zeway area. Five groups (42\%) suggested that overgrazing by local and seasonal nomads in wood and wetland habitats at the lake has reduced roosting, breeding and feeding habitats as well as species diversity and abundance of waterbirds.

The majority $(83 \%)$ of the discussants thought insufficient and unpredictable rainfall, destruction of aquatic vegetation, and associated food shortages contributed to changes in waterbird species distributions. One focus group discussants thought there was no change in species distributions and another did not know whether there was change or not.

All (100\%) groups suggested that an increase in temperature and long dry seasons in the past 3-4 decades have contributed to the decline in waterbird species composition and changed their distribution. Twelve (100\%) discussants stated that impacts of the long dry seasons in the area have affected plant species phenology, altered bird species spatial and temporal migration patterns, and reduced bird species richness and abundance. 
The focus groups were divided into in what they thought were the most important drivers of changes in local biodiversity. Five (42\%) indicated climate change as the more important environmental variable that negatively impacted biodiversity and the productivity of the natural resources of the area. Another five (42\%) groups indicated equal impacts of climate and land use changes. One group thought climate change and deforestation were the most important drivers, while the remaining group did not identify any driver.

Five (42\%) focus goup discussants indicated positive views towards the occurrence of bird species in the Lake Zeway area. The discussants loved birds because birds' plumage and songs are attractive and their presence in the area is interesting to them. Four (33\%) groups thought the occurrence of birds was good because they are the creation of God and have the right to exist in the environment and two (17\%) groups thought their occurrence was bad, because they destroy crops they grow. One group (8\%) was indifferent.

According to the respondents, the primary value of Lake Zeway is its use for fish production. Farming activeties were ranked next most highly, breeding bird habitat was third and tourist attraction was ranked lowest (Table 4). Congruence in rankings among groups was significantly higher than expected by chance $\left(x^{2}{ }_{4}=25.88, p<\right.$ 0.01).

\section{DISCUSSION}

Land conversion and climate changes can have significant impacts on biodiversity and associated ecosystem services (Finlayson et al., 2006; Jetz et al., 2007; Ayenew, 2009; Gudina, 2011). Based on the perceptions of experienced local people, this study also revealed signs of reduced waterbird species diversity as related to increased conversion of wood and wetlands to irrigated agriculture around Lake Zeway.

Comparisons of small lagoons and large fragmented wetland habitats in Brazil indicated lower waterbird species richness, diversity, and abundance in the fragmented wetlands (Guadagnin et al., 2005). Congruent to this, the present study showed that apparent declines might be caused by fragmentation of Lake Zeway wetland habitats by small scaled irrigated agricultures has contributed to its waterbird species diversity and abundance decline.

Among the threats to Ethiopian wetlands and their biodiversity are deforestation, overfishing and overgrazing, the consequences of high human population pres-sure (Sisay, 2003). These changes coincide with the cur-rent study, which identified deforestation in the lake's catchments as a perceived cause of decline in bird species composition and abundance, and distribution change. The study further indicated that overgrazing by livestock in the areas surrounding the lake has reduced vegetation cover, nest sites, birds' food, habitats, and as a result the birds. Other studies have also revealed impacts of habitat des- truction and overgrazing on cover, nest sites, and food availability to birds in the area (Hegsdijsk and Jansen, 2006; Jansen et al., 2007; Melesse et al., 2009; Mengesha et al., 2011). The inter-views in this study revealed that terrestrial habitat destruction, siltation, and water diversions may have caused a contraction in the birds' habitat, reduced their population sizes and changed their distribution. Other studies have also indicated a contraction of wetland habitats and decreased lake volume due to woodland destruction and the water diversion for irrigated agriculture (EWNHS, 1996; Legesse et al., 2003; Ayenew et al., 2009).

The present study suggested chemical release into the lake, from the floriculture and horticulture enterprises, was perceived to have killed fishes and contributed to the decline of piscivorous bird populations. Jansen et al. (2007) and Birdlife International, (2012) have also suggested that increased pollution may impact the fisheries and aquatic birdlife of Lake Zeway. Reduced bird species diversity and abundance at the lake may also be caused by direct kill by pesticides. During the past 30 years, the Ethiopian government used helicopters to spray pesticides that kill bird species that are considered crop pests in the vicinity of Lake Zeway (Bruggers and Jaeger, 1982; Cheke, 2003). The imapct of chemicals and pesticides on birds, their habitats and reproduction have been found in many studies to be an indirect impact of land use changes (Jaeger and Erickson, 1980; Sisay, 2003; Ellott, 2006; Sharma et al., 2007; Brambilla et al., 2011; Koleček et al., 2010).

The present study revealed that fisheries were the most important value of Lake Zeway to the local people, and that there were both local and commercial fishing. These fisheries were thought to have contributed to fish scarcity through overfishing (Sisay, 2003), which in turn, the discassants percived as contributed to a decline in the diversity and abundance of waterbirds. Members of the focal groups also persumed that the abundance of worms in the lake may have declined due to the introduced African catfish which could have altered the prey base for some waterbirds.

Increased temperature and decreased rainfall, via their effects on lake depth and width, were also thought to have contributed to the decline in waterbird species diversity. Increased evapo-transpiration due to higher temperature has previously been reported in the same area (Misganaw, 2007).

Migration can enable mobile animals such as bird species to escape harsh environmental conditions (Rivalan et al., 2007). Nevertheless, climate change alters timing of migration, breeding performance, population size and distribution of birds (Crick, 2004; Levinsky, 2007). Observations by the local people suggest that waterbirds movements away from the area of the Lake Zeway, to escape the long drought and high temperatures, contributed to reduced diversity and abundance of birds. Overall, the observations of local people suggest that, climate chan- 
ges combined with LULCC or in isolation have put great stress on Lake Zeway's hydrodynamics, reduced its waterbird diversity and abundance, and changed the birds' distributions. The lake is highly valued by local people for fish production, farming and breeding birds, but not for tourist attraction at present. Conservation measures that reduce the impacts of LULCC and climate changes on Lake Zeway's water and biodiversity resources need be in place to conserve its resources and prevent the lake from drying

\section{ACKNOWLEDGEMENTS}

We are grateful to the districts and Kebeles offices, in particular, the offices of agriculture, land administration and environment of Admin Tulu Jedo Komolcha, Dugda Bora and Zeway Dugda for their invaluable assistance and help in making the focus group discussants available. Moreover, we thank the key informants and the focus group discussants. Our gratitude also goes to individuals who assisted us during data collection. We are especially indebted to Fekadu Teferra who gave his unreserved guidance in the social survey design. We also greatly thank our driver Alemahyeu Abiso both for his driving services and his assistance in organizing the FGD. We are greatly indebted to Chris Elphick who helped in editing the manuscript. Finally, we thank Addis Ababa University for the financial support provided.

\section{REFERENCES}

Abebe YD, Geheb K (2003). Wetlands of Ethiopia. proceedings of a seminar on the resources and status of Ethiopia's wetlands. IUCN: Gland.

Asefa A (2008). Honey production in the southern Harenna forest of the Bale mountains national park, Ethiopia: in economic and conservation perspective. Ethio. J. Biol. Sci. 7: 17-33.

Ayenew T (2002). Recent changes in the level of lake Abiyata, central main Ethiopian rift. J. Hydro. Sci. 47: 493-503.

Ayenew T (2009). Natural lakes of Ethiopia. Addis Ababa University Press: Addis Ababa. pp.1-40.

BirdLife International (2012). Important bird areas factsheet: Lake Zeway. Downloaded from http://www.birdlife.org on 24/04/2012

Brambilla M, Casale F, Bergero V, Bogliani G, Crovetto G M, Falco R, Roati M, Negri I (2011). Glorious past, uncertain present, bad future? Assessing effects of land-use changes on habitat suitability for a threatened farmland bird species. Biol. Conserv. 143: 2770-2778.

Bruggers RL, Jaeger MM (1982). Bird pest and crop protection strategies for cereals of the semi-aired African tropics. International Crops Research Institute for the Semi-Arid Tropics, Pretoria. pp. 135.

Cheke RA (2003). Forecasting movements and breeding of the Redbilled Quelea bird in southern Africa and improved control strategies. Natural Resources institute, University of Greenwich. p.76.

Crick HQP (2004). The impacts of climate change on birds. Ibis 146: 4856.

Devers KJ, Frankel RM (2000). Study design in qualitative research-2: Sampling and data collection strategies. A practical advice. Educ. Health (Abingdon) 13(2): 263-271.

Ellis E, Pontius R (2011). Land-use and land-cover change. In: Encyclopedia of Earth, Cleveland C. J. (ed.). Environmental Information Coalition. Washington, D. C. pp.1-20.

Ellott CCH (2006). Bird population explosions in agro-ecosystems the quelea, Quelea quelea. Case history. Acta Zool Sinica 52: 554-560.
EWNHS- Ethiopia Wildlife and Natural History Society (1996). Important Bird Areas of Ethiopia (IBA), a first inventory. Ethiopian Wildlife and Natural History Society, Addis Ababa. pp. 5-160.

FAO-Food and Agricultural Organization (2009). The linkage with sustainability, food security and climate change impacts. Food and Agricultural organization of the United Nations. pp.1-45.

Finlayson CM, Gitay H, Bellio MG, van Dam R, Taylor I (2006). Climate variability and change and other pressures on wetlands and waterbirds: impacts and adaptation. In: Waterbirds around the world, (Boere GC., Galbraith C.A, Stroud DA (eds.) The Stationery Office, Edinburgh, UK. pp. 88-97.

Gibbard S G, Caldeira K, Bala G, Phillips TJ, Wickett M (2005). Climate effects of global land cover change S. Geophysical Research Letters. University of California, California.

Guadagnin DL, Peter ÂS, Fernando L, Perello C, Maltchik L (2005). Spatial and temporal patterns of waterbird assemblages in fragmented wetlands of Southern Brazil. J. Waterbird Soc. 28:261272.

Gudina A (2011). Integrated assessment of livelihood dependence on services provided by ecosystems along the western shoreline of Lake Zeway. MSc. thesis, Wageningen UR. p.94.

Hengsdijk $\mathrm{H}$, Jansen $\mathrm{H}$ (2006). Agricultural development in the central Ethiopian rift valley. A desk-study on water-related issue and knowledge to support policy dialogue. Plant Research International B. V. , Wageningen UR. pp. 5-65.

IPCC-Intergovernmental Panel of Climate Change (2001). Climate Change 2001. In: The scientific basis; Third assessment report of working group I.pp.1-210,. Albritton L G, Meira Filho D.L (eds.), Cambridge University Press, Cambridge.

Jansen $\mathrm{H}$, Hendsidijk $\mathrm{H}$, Legesse $\mathrm{D}$, Ayenew $\mathrm{T}$, Hellegrs $\mathrm{P}$, Spliesthoh $H$ (2007). Land and water resources assessments in Ethiopian central rift valley: ecosystem for water, food and economic development in the Ethiopian central rift valley. Alterra: Wageningen. pp. 1-85.

Jetz W, Wilson DS, Dobson AP (2007). Projected impacts of climate and land use changes on global diversity of birds. Plos Biol. 5: 12111219.

Koleček J, Reif J, Astny KS, Bejček V'R (2010). Changes in bird distribution in central European countries between 1985-1989 and 2001-2003. J. Ornith. 151: 923-932.

Legesse D, Vallet-Coulomb C, Gasse F (2003). Hydrological response of a catchment to climate and land use changes in Tropical Africa: A case study in South Central Ethiopia. J. Hydrol. 275: 67-85.

Legesse D, Vallet-Coulomb C, Gasse F (2004). Analysis of the hydrological response of a tropical terminal lake, Lake Abiyata (Main Ethiopian Rift Valley) to changes in climate and human activities. Hydrol. Proc. 18: 487-504.

Levinsky I (2007). Species distributions and climate change. Linking the past and the future. Ph.D. thesis, University of Copenhagen, 1-55.

Lukkarinen MH, Kuitunen M, Suhonen J (2011). The effect of changes in land use on waterfowl species turnover in Finnish boreal lakes. Ornis Fennica 88: 1-10.

Maynard K, Royer JF (2004). Effects of "realistic" land-cover change on a greenhouse-warmed African climate. Clim. Dyn. 22: 343-358.

Melesse A, Abtew W, Dessalegne T (2009). Evaporation estimation of rift valley lakes: comparison of Models. Sensors 9: 9603-9615.

Mengesha G, MamoY, Bekele A (2011). Terrestrial bird community structures in the disturbed and undisturbed areas of Abijata Shalla lake national park, Ethiopia. Int. J. Biodivers. Conserv. 3: 389-404.

Misganaw T (2007). Assessment of the ecological impacts of floriculture Industries using physico-chemical parameters and benthic macroinvertebrates metric index along Wedecha River, Debrezeit, Addis Ababa University, Addis Ababa. p.185

Olaka LA, Odada EO, Truauth MH, Olaga OO (2010). The sensitivity of east African rift lakes to climate change fluctuation. J. Paleolimnol. 44: 629-644.

Oster M (1978). Birds and culture. Doubleday \& Company, Inc.: New York.

Reed JM, Elphick CS, Leno EN, Zuur AF (2011). Long-term population trends of endangered Hawaiian waterbirds. Popul. Ecol. 53: 473-481.

Rivalan P Frederiksen M, Lois G, Julliard R (2007). Contrasting responses of migration strategies in two European thrushes to 
climate change. Glob. Chang. Biol.13: 275-287.

Sanz JJ (2002). Climate change and birds: have their ecological consequences already been detected in the Mediterranean region? Ardeola 49: 109-120.

Sharma E, Bhuchar S, Ma X, Kothyari BP (2007). Land use change and its impact on hydro-ecological linkages in Himalayan watersheds. Trop. Ecol. 48: 151-161.

Sisay $L$ (2003). Biodiversity potentials and threats to the southern Rift Valley lakes of Ethiopia. In: Wetland of Ethiopia. Proceedings of a seminar on the resources and status of Ethiopia's wetlands. (Yilma D, Geheb K eds.), IUCN; Gland. pp.18-24.

Syvertsen PO (1995). Wintering water birds on Ethiopian rift valley lake. Walia 16: 3-16.

Teddlie C, Yu F (2007). Mixed Methods Sampling: A typology with examples. J. Mixed Methods Res. 1: 77-100.

Tongco MD (2007). Purposive sampling as a tool for informant selection. Asian J. Plants People Appl. Res. 5: 147-158.
Waltert M, Mardiastuti A, Muhlenberg M (2004). Effect of land use on bird species richness in Sulawesi, Indonesia. Conserv. Biol. 18: 13391346.

Warren DM, Rajasekaran B (1993). Putting local knowledge to good use. Int. Agric. Dev. 13: 8-10.

Wurburton H, Martin A (1999). Local people's knowledge in natural resources research. Socio-economic Methodologies for Natural Resources Research. Chatham: Natural Resources institute.

Zeray L, Roehrig J, Alamirew D (2006). Climate change impact on Lake Zeway watershed water availability. International Agricultural Research for Development, Bonn. pp.1-25. 
Appendix 1. Questions posed to the local people during the interview.

\begin{tabular}{|c|c|}
\hline $\begin{array}{l}\text { Personal information } \\
\text { (Wa'eeEngnyumaaoffii) }\end{array}$ & Sex (Sala): Male (Dhira) - Female (dubartii), Age (Umurii) \\
\hline $\begin{array}{l}\text { Occupation } \\
\text { (milikitaa X qodhii). }\end{array}$ & Farmer (QoteBulaa), Merchant (Daldalaa), Government Employee (Hojettamotumma), Other (Kabirra) \\
\hline $\begin{array}{l}\text { Educational background } \\
\text { (HalaaBarnotaa) }\end{array}$ & $\begin{array}{l}\text { Below grade } 6 \text { (kutaajaa'agaddi), } 10^{\text {th }} \text { grade complete (Kutaa } 10 \text { xumeree), } 12 \text { grade complete } \\
\begin{array}{l}\text { (Kuttakudhlamaxumuree), Diploma graduate } \\
\text { (barumsaDgriijalbaanebifamme), MSc. /MA (Degriilamatatinebifamee) }\end{array}\end{array}$ \\
\hline \multicolumn{2}{|c|}{ Longevity in this area in Years (Baraaturtiinanno kana wagaadhan) } \\
\hline $\begin{array}{l}\text { Knowledge of the Lake } \\
\text { Zeway } \\
\text { (bekuumisaharaaillalichise } \\
\text { e) }\end{array}$ & 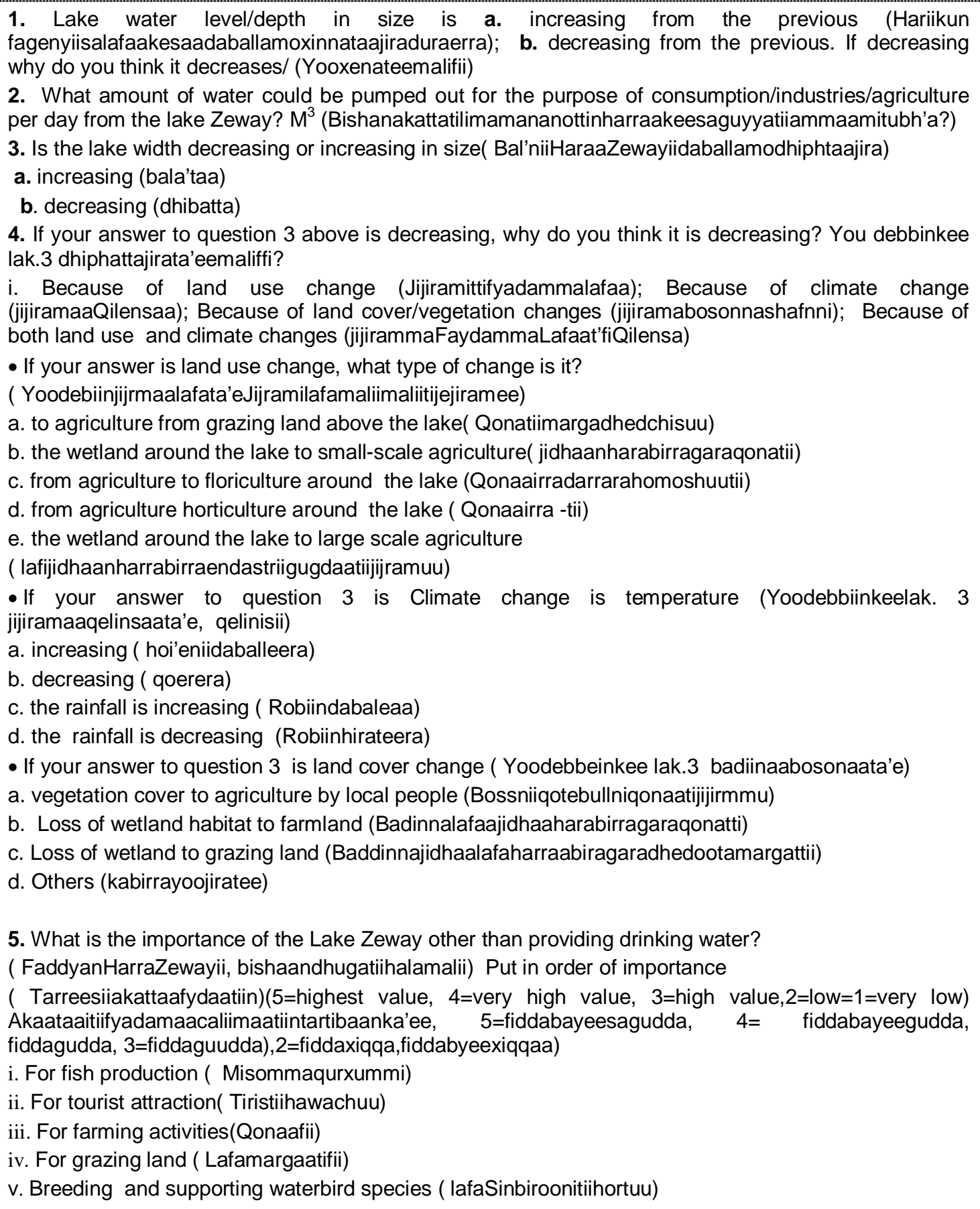 \\
\hline
\end{tabular}


Appendix 1. Contd.

\begin{tabular}{|c|c|}
\hline & 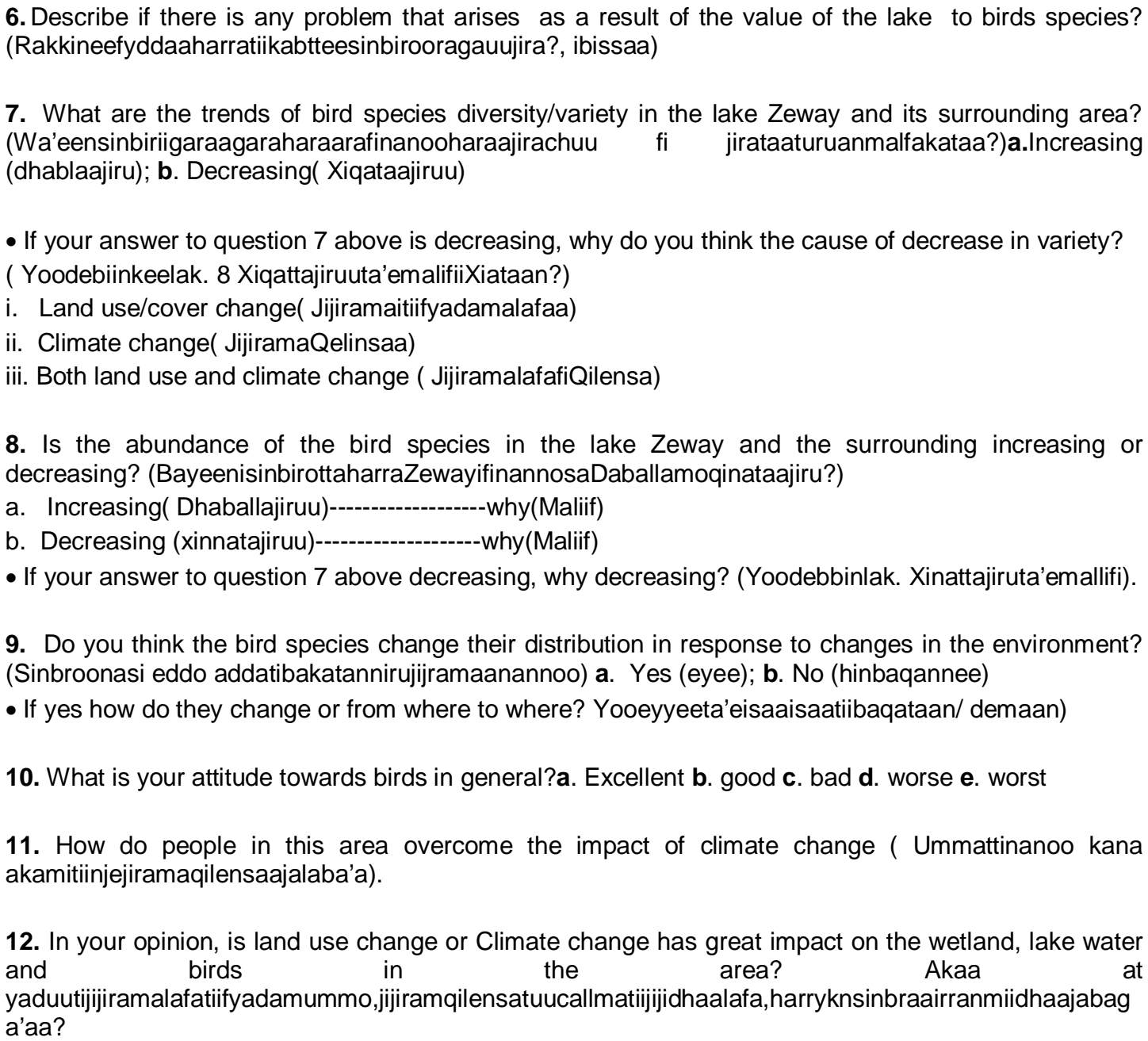 \\
\hline $\begin{array}{l}\text { Personal information } \\
\text { (Wa'eeEngnyumaaoffii) }\end{array}$ & Sex (Sala): Male (Dhira) ---Female (dubartii), age (Umurii) \\
\hline $\begin{array}{l}\text { Occupation } \\
\text { (milikitaa } X \text { qodhii). }\end{array}$ & Farmer (QoteBulaa), Merchant (Daldalaa), Government Employee (Hojettamotumma), Other (Kabirra) \\
\hline $\begin{array}{l}\text { Educational background } \\
\text { (HalaaBarnotaa) }\end{array}$ & 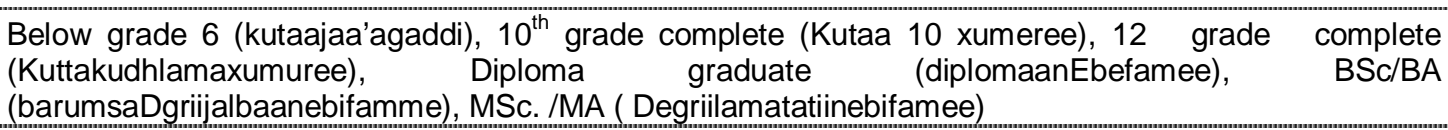 \\
\hline \multicolumn{2}{|c|}{ Longevity in this area in Years (Baraaturtiinanno kana wagaadhan) } \\
\hline $\begin{array}{l}\text { Knowledge of the Lake Zeway } \\
\text { (bekuumisaharaaillalichisee) }\end{array}$ & $\begin{array}{l}\text { Lake water level/depth in size is a. increasing from the previous (Hariikun } \\
\text { fagenyiisalafaakesaadaballamoxinnataajiraduraerra); b. decreasing from the previous. If decreasing } \\
\text { why do you think it decreases/ (Yooxenateemalifii) } \\
\text { 2. What amount of water could be pumped out for the purpose of consumption/industries/agriculture } \\
\text { per day from the lake Zeway? } \mathrm{M}^{3} \text { (Bishanakattatilimamananottinharraakeesaguyyatiiammaamitubh'a?) } \\
\text { 3. Is the lake width decreasing or increasing in size( Bal'niiHaraaZewayiidaballamodhiphtaajira) a. } \\
\text { increasing (bala'taa) b. decreasing (dhibatta) } \\
\text { 4. If your answer to question } 3 \text { above is decreasing, why do you think it is decreasing? You debbinkee } \\
\text { lak.3 dhiphattajirata'eemaliffi? } \\
\text { i. Because of land use change (Jijiramittifyadammalafaa); Because of climate change } \\
\text { (jijiramaaQilensaa); Because of land cover/vegetation changes (jijiramabosonnashafnni); Because of } \\
\text { both land use and climate changes (jijirammaFaydammaLafaat'fiQilensa) } \\
\text { - If your answer is land use change, what type of change is it? }\end{array}$ \\
\hline
\end{tabular}


(Yoodebiinjijrmaalafata'eJijramilafamaliimaliitijejiramee)

a. to agriculture from grazing land above the lake( Qonatiimargadhedchisuu)

b. the wetland around the lake to small-scale agriculture( jidhaanharabirragaraqonatii)

c. from agriculture to floriculture around the lake (Qonaairradarrarahomoshuutii)

d. from agriculture horticulture around the lake ( Qonaairra -tii)

e. the wetland around the lake to large scale agriculture

( lafijidhaanharrabirraendastriigugdaatiijijramuu)

- If your answer to question 3 is Climate change is temperature (Yoodebbiinkeelak. 3 jijiramaaqelinsaata'e, qelinisii)

a. increasing ( hoi'eniidaballeera)

b. decreasing ( qoerera)

c. the rainfall is increasing (Robiindabaleaa)

d. the rainfall is decreasing (Robiinhirateera)

- If your answer to question 3 is land cover change ( Yoodebbeinkee lak.3 badiinaabosonaata'e)

a. vegetation cover to agriculture by local people (Bossniiqotebullniqonaatijijirmmu)

b. Loss of wetland habitat to farmland (Badinnalafaajidhaaharabirragaraqonatti)

c. Loss of wetland to grazing land (Baddinnajidhaalafaharraabiragaradhedootamargattii)

d. Others (kabirrayoojiratee)

5. What is the importance of the Lake Zeway other than providing drinking water?

(FaddyanHarraZewayii, bishaandhugatiihalamalii) Put in order of importance

(Tarreesiiakattaafydaatiin)(5=highest value, 4=very high value, 3=high value,2=low=1=very low) Akaataaitiifyadamaacaliimaatiintartibaanka'ee, $5=$ fiddabayeesagudda, $4=$ fiddabayeegudda, fiddagudda, 3=fiddaguudda),2=fiddaxiqqa,fiddabyeexiqqaa)

i. For fish production ( Misommaqurxummi)

ii. For tourist attraction( Tiristiihawachuu)

iii. For farming activities(Qonaafii)

iv. For grazing land ( Lafamargaatifii)

v. Breeding and supporting waterbird species ( lafaSinbiroonitiihortuu)

6. Describe if there is any problem that arises as a result of the value of the lake to birds species? (Rakkineefyddaaharratiikabtteesinbirooragauujira?, ibissaa)

7. What are the trends of bird species diversity/variety in the lake Zeway and its surrounding area? (Wa'eensinbiriigaraagaraharaarafinanooharaajirachuu fi jirataaturuanmalfakataa?)a.Increasing (dhablaajiru); b. Decreasing( Xiqataajiruu)

- If your answer to question 7 above is decreasing, why do you think the cause of decrease in variety? (Yoodebiinkeelak. 8 Xiqattajiruuta'emalifiiXiataan?)

i. Land use/cover change( Jijiramaitiifyadamalafaa)

ii. Climate change( JijiramaQelinsaa)

iii. Both land use and climate change ( JijiramalafafiQilensa)

8. Is the abundance of the bird species in the lake Zeway and the surrounding increasing or decreasing? (BayeenisinbirottaharraZewayifinannosaDaballamoqinataajiru?)

a. Increasing( Dhaballajiruu)-----------------why(Maliif)

b. Decreasing (xinnatajiruu)------------------why(Maliif)

- If your answer to question 7 above decreasing, why decreasing? (Yoodebbinlak. Xinattajiruta'emallifi).

9. Do you think the bird species change their distribution in response to changes in the environment? (Sinbroonasi eddo addatibakatannirujijramaanannoo) a. Yes (eyee); b. No (hinbaqannee)

- If yes how do they change or from where to where? Yooeyyeeta'eisaaisaatiibaqataan/ demaan) 
Appendix 1. Contd.

10. What is your attitude towards birds in general?a. Excellent b. good c. bad d. worse e. worst

11. How do people in this area overcome the impact of climate change (Ummattinanoo kana akamitiinjejiramaqilensaajalaba'a).

12. In your opinion, is land use change or Climate change has great impact on the wetland, lake water and birds in the area? Akaa yaduutijijiramalafatiifyadamummo,jijiramqilensatuucallmatiijijidhaalafa, harryknsinbraairranmiidhaajabag a'aa? 